\title{
PARADIGMA FIKIH SUNGAI: TELAAH KEBIJAKAN PEMERINTAH DAN PEMAHAMAAN MASYARAKAT TERHADAP KONSERVASI SUNGAI DI KOTA BANJARMASIN
}

\author{
Budi Rahmat Hakim ${ }^{*}$ \\ Abdul Hafiz Sairazi ${ }^{2 *}$ \\ Nasrullah ${ }^{3 *}$ \\ ${ }^{*}$ Fakultas Syariah Universitas Islam Negeri Antasari. \\ ${ }^{* 2}$ Fakultas Syariah Universitas Islam Negeri Antasari) \\ ${ }^{* 3}$ Fakultas Hukum Uniska MAB Banjarmasin)
}

\begin{abstract}
Banjarmasin city is a city that has so many rivers and is inhabited by the majority of Muslims, who should understand about the importance of the rivers' benefits because Islam teaches it. However, in reality there are still many people who throw garbage into the river, even build settlements along the river. The river conservation policy has been regulated in various regulations by Government of the Banjarmasin City, and has even become a strategic issue in the spatial planning of Banjarmasin City 2013-2032. This policy received a positive response from the people of Banjarmasin City, but their participation and involvement in the river conservation was still low. The purpose of this study is to determine the effectiveness of the implementation of government policies on river conservation in Banjarmasin City and to know the response of the Banjarmasin Muslim community to government policies related to river conservation in Banjarmasin City, and to know the extent to which the culture of religious comprehension and perceptions of the Muslim community in Banjarmasin City can support the river utilization and conservation efforts.
\end{abstract}

Keywords: river fiqh, policy, comprehension, river conservation

\begin{abstract}
Abstrak
Kota Banjarmasin merupakan kota yang memiliki begitu banyak aliran sungai dan dihuni mayoritas oleh kaum muslim, yang seyogyanya mengerti akan pentingnya manfaat sungai karena Islam mengajarkan hal tersebut. Namun kenyataannya masih banyak masyarakat yang membuang sampah ke aliran sungai bahkan membangun pemukiman di bantaran sungai. Kebijakan konservasi sungai telah diatur dalam berbagai regulasi oleh Pemerintah Kota Banjarmasin, bahkan menjadi isu strategis dalam perencanaan tata ruang wilayah Kota Banjarmasin 2013-2032. Kebijakan tersebut mendapat respon positif dari masyarakat Kota Banjarmasin, namun partisipasi dan keterlibatan mereka terhadap konsevasi sungai masih rendah. Penelitian ini bertujuan untuk mengetahui efektivitas implementasi kebijakan pemerintah terhadap konservasi sungai di Kota Banjarmasin dan mengetahui respon masyarakat muslim Banjarmasin terhadap kebijakan pemerintah terkait konservasi sungai di Kota Banjarmasin, serta mengetahui sejauh mana kultur pemahaman keagamaan dan persepsi masyarakat muslim di Kota Banjarmasin yang dapat mendukung terhadap upaya pemanfaatan dan konservasi sungai.
\end{abstract}

Kata Kunci: fikih sungai, kebijakan, pemahaman, konservasi sungai. 
Budi Rahmat Hakim, Abdul Hafiz Sairazi dan Nasrullah, 202I,Paradigma Fikih Sungai: Telaah Kebijakan Pemerintah dan Pemahamaan Masyarakat terhadap Konservasi Sungai di Kota Banjarmasin

\section{PENDAHULUAN}

Salah satu karunia Allah yang tidak ternilai harganya adalah sungai. Dari sejarah dapat diketahui bahwa sungai memiliki peranan yang sangat besar bagi perkembangan peradaban manusia di seluruh dunia ini. Mengingat demikian besarnya manfaat serta pentingnya peranan dan fungsi sungai bagi umat manusia, serta bahaya yang ditimbulkannya, maka sudah semestinya sumber daya air itu dikelola secara integratif, komprehensif dan holistik. (Kodoatie: 28)

Untuk menjamin keberlangsungan kehidupan di alam semesta, air menempati posisi yang sangat penting. Baik dalam tinjauan normatif, maupun ilmu fisika, air adalah salah satu sub struktur inti dalam susunan semesta alam. Oleh karena itu sumber-sumber ajaran Islam, yang termaktub dalam Alquran dan Hadis Nabi saw serta hasil-hasil ijtihad ulama telah membahas tema air dalam berbagai perspektif. Subtansi misi ajaran Islam adalah semangat kemaslahatan, dimana semua pihak, siapa pun termasuk pemerintah dan juga individu-individu dalam sebuah masyarakat bertanggung jawab secara bersama-sama dalam mewujudkan segala bentuk aspek kemaslahatan tersebut. terkait hal ini tentu sesuai dengan konsep maslahah yang diutarakan oleh Wahbah az-Zuhaili sebagaimana yang dikutip Ariyadi (2017: 36) bahwa cakupan maslahah yang dimaksud harus bersifat umum, sehingga dapat mewujudkan manfaat bagi banyak orang.

Dalam konteks memelihara kemaslahatan sumber daya air dan lingkungan sungai, kebijakan pemerintah sebagai regulator sudah seharusnya berorientasi secara efektif ke arah ini.

Banjarmasin adalah sebuah kota yang berada di Provinsi Kalimantan Selatan yang selama ini dikenal dengan julukan Kota Seribu Sungai yang menunjukkan banyaknya jumlah sungai di kota ini secara kuantitas. Berdasarkan data BPS Kota Banjarmasin jumlah sungai besar dan kecil di Kota Banjarmasin sebanyak 190 buah yang tersebar di lima kecamatan. (https://banjarmasinkota.bps.go.id : 2019). Namun dari sejumlah sungai tersebut hanya 102 buah sungai yang dinyatakan masih aktif berfungsi (https://banjarmasinkota.bps.go.id : 2019), termasuk sungai yang tercemar, dangkal dan sempit, sisanya sudah tidak berfungsi lagi. (https://banjarmasin. tribunnews.com: 2019)

Fenomena yang nampak di lapangan masih banyak terlihat kenyataan yang terkesan berbanding terbalik dengan adanya sungai-sungai yang tidak terjaga kelestariannya, seperti menyempit, kotor, dan bahkan tidak berfungsi lagi. Mulai dari fakta banyaknya bangunan yang didirikan di bantaran (bahkan di atas sungai), masih terlihatnya sampah-sampah yang menggenangi aliran sungai dan sebagainya.

Realitas keberadaan dan kondisi sungai di Kota Banjarmasin sebagaimana digambarkan terdahulu mengasumsikan kesan kurangnya perhatian dari pihak pemerintah dan masyarakat terhadap pengelolaan dan pelestarian sungai sebagaimana mestinya. Dalam mengelola sungaisungai, baik pemerintah maupun masyarakat hanya terbatas pada aspek pemanfaatan, sedangkan aspek pelestarian dan aspek pengendaliannya terkesan seperti terabaikan. Padahal baik hukum positif maupun hukum Islam, yang seyogyanya menjadi pedoman bagi pemerintah dan masyarakat muslim, sama-sama telah mengatur ketiga aspek pengelolaan sungai tersebut.

Realitas yang memprihatinkan itu tentu saja tidak dapat dibiarkan. Sungai-sungai yang sudah mati dan ditutupi rumah-rumah dan bangunanbangunan lainnya memang tidak akan dapat lagi dipulihkan peranan dan fungsinya. Sebab untuk itu diperlukan biaya yang sangat tinggi dan mahal, terutama untuk biaya ganti rugi terhadap penggusuran rumah-rumah dan bangunanbangunan yang telah menutupnya. Sebaliknya, sungai-sungai yang masih terbuka dan mengalir harus dipelihara kelestariannya dan dikelola sebagaimana mestinya, sedangkan sungai-sungai yang masih terbuka, tetapi tidak mengalir lagi masih dapat diselamatkan dan dikelola secara proporsional sehingga dapat kembali berfungsi sebagaimana mestinya.

Pelestarian dan pemulihan kembali peranan dan fungsi sungai-sungai di Kalimantan Selatan dan di Banjarmasin pada khususnya tidak akan dapat dilaksanakan, tanpa ada will (kemauan) dari pemerintah dan partisipasi masyarakat. Masalah sungai adalah masalah yang sangat menarik untuk 
dibahas, khususnya bagi masyarakat yang hidup dalam lingkungan perairan seperti Banjarmasin. Sungai hanyalah sebagian dari masalah kehidupan masyarakat dalam lingkungan berair. Masalah yang lebih besar adalah bagaimana mendorong masyarakat agar menjaga sumber-sumber air, termasuk sungai.

Beranjak dari latar belakang dan dasar pemikiran tersebut, penelitian ini dimaksudkan untuk menelaah efektivitas implementasi sejumlah kebijakan yang dibuat pemerintah Kota Banjarmasin dalam upaya konservasi sungai sekaligus juga memotret pemahaman masyarakat Banjarmasin dalam merespon kebijakan tersebut dan persepsi mereka terhadap pemanfaatan sumber daya air serta upaya pelestarian sungai berdasarkan kultur sosial maupun pemahaman ajaran Islam yang dianut. Sejumlah jawaban penelitian akan dirumuskan menjadi bahan analisis untuk memetakan pola dan paradigma konservasi sungai yang berperspektif maslahat sesuai hukum Islam.

\section{METODE}

Penelitian ini merupakan penelitian lapangan (field research), yaitu penelitian yang dilakukan pada masyarakat di Kota Banjarmasin dan pihak pengambil kebijakan terkait regulasi yang berkenaan dengan konservasi lingkungan sungai. Subjek penelitian adalah masyarakat muslim Kota Banjarmasin yang tinggal di bantaran sungai dan pihak pemerintah Kota Banjarmasin melalui dinas terkait. Adapun objek penelitiannya adalah gambaran paradigma pemahaman masyarakat konservasi sungai dan kebijakan pemerintah terhadap konservasi sungai di Banjarmasin. Teknik pengumpulan data yang digunakan adalah wawancara, observasi dan metode dokumentasi. Analisis yang digunakan adalah secara deskriptif. Analisis juga menggunakan modal teoritik yang dimiliki oleh peneliti dengan cara pengayaan atas temuan data sehingga bermakna dalam konteks terapan atau kebijakan tertentu secara empiris.

\section{HASIL DAN PEMBAHASAN}

\section{A. Gambaran Umum Lokasi Penelitian}

Banjarmasin adalah ibukota Provinsi Kalimantan Selatan, dan menduduki peringkat pertama sebagai wilayah dengan jumlah penduduk terbesar (16,76 persen), yaitu mencapai 700.869 jiwa di tahun 2018 (Badan Pusat Statistik Kota Banjarmasin: 20). Kota
Banjarmasin tak terpisahkan dari sungai sehingga Banjarmasin mendapat julukan "kota seribu sungai". Data dari Dinas Kimprasko Banjarmasin menunjukkan pada 1997 di lbu Kota Kalimantan Selatan itu terdapat 1 I7 sungai, kemudian pada 2002 berkurang menjadi 70 sungai, lalu pada 2004 sampai sekarang hanya tinggal 60 sungai (https://id. wikipedia.org: 2020). Posisi Banjarmasin yang terletak pada suatu delta yang dikelilingi oleh Sungai Martapura dan Sungai Barito berimplikasi pada budaya dan kehidupan masyarakat yang kental dengan permukiman, perdagangan, dan transportasi (Yayuk: |3|-|32). Agama mayoritas masyarakat Kota Banjarmasin adalah agama Islam yaitu sekitar $95.54 \%$, agama lain yang dianut masyarakat Banjarmasin, yaitu Kristen, Katolik dan Buddha yang rata-rata dianut masyarakat keturunan Tionghoa dan pendatang. (https://id. wikipedia.org: 2020)

\section{B. Implementasi Kebijakan Pemerintah Kota Banjarmasin terhadap Konservasi Sungai}

Strategi kebijakan konservasi sungai yang dilakukan Pemerintah Kota Banjarmasin merupakan bagian dari kebijakan pengelolaan sungai yang sudah dituangkan dalam visi dan misi Walikota Banjarmasin 2016-202I.

Untuk mencapai tujuan dari visi kota Banjarmasin yang berbunyi: “Kayuh Baimbai Manuju Banjarmasin Baiman (Bertakwa, Aman, Indah, Maju, Amanah dan Nyaman)", maka pengelolaan sungai diwujudkan pada misi ketiga, yaitu: Mewujudkan Kota Banjarmasin indah dengan penataan kota berbasis tataruang berbasis sungai, guna terwujud kota yang asri dan harmoni; dan juga pada misi yang keempat, yaitu: Mewujudkan Kota Banjarmasin yang maju dengan penguatan perekonomian melalui sektor perdagangan, perindustrian dan pelabuhan dengan memperhatikan pemerataan pendapatan, meningkatkan taraf pendidikan, pengembangan dan pelestarian budaya Banjar, kuliner Banjar serta pariwisata sungai untuk mencapai kesejahteraan masyarakat. (Dinas Kebudayaan dan Pariwisata: 23)

Strategi kebijakan konservasi sungai Kota Banjarmasin dirumuskan juga dengan mengacu kepada Rencana Tata Ruang Wilayah (RTRW) Kota Banjarmasin 20I3-2032, yaitu sebagaimana yang digariskan pada Pasal 3 Ayat (I) bahwa Strategi penataan sungai-sungai terdiri atas: a) 
Budi Rahmat Hakim, Abdul Hafiz Sairazi dan Nasrullah, 202I,Paradigma Fikih Sungai: Telaah Kebijakan Pemerintah dan Pemahamaan Masyarakat terhadap Konservasi Sungai di Kota Banjarmasin

merevitalisasi sungai melalui koordinasi dengan UPT Kementerian PU yang mengelola wilayah Sungai Barito; b) melakukan peremajaan kawasan sepanjang sungai; dan c) melaksanaan penyediaan perahu untuk kebutuhan wisatawan.

Konservasi sungai yang dilaksanakan oleh Pemerintah Kota Banjarmasin merupakan pelaksanaan dari Konservasi Sumber Daya Air yang diamanatkan dalam Undang-Undang Nomor 7 Tahun 2004 tentang Sumber Daya Air, dan yang dimaksud dengan konservasi sumber daya air adalah upaya memelihara keberadaan serta keberlanjutan keadaan, sifat, dan fungsi sumber daya air agar senantiasa tersedia dalam kuantitas dan kualitas yang memadai untuk memenuhi kebutuhan makhluk hidup, baik pada waktu sekarang maupun yang akan datang.

Untuk melaksanakan konservasi sungai sebagaimana yang diatur dalam Undang-Undang tersebut, Peraturan Pemerintah Nomor 38 Tahun 201 I tentang Sungai pada Pasal 20 Ayat (I) ditegaskan bahwa konservasi dilakukan melalui beberapa kegiatan, yaitu perlindungan sungai dan pencegahan pencemaran air sungai. Kemudian Ayat (2) menjelaskan bahwa perlindungan sungai dilakukan melalui perlindungan terhadap palung sungai, sempadan sungai, danau paparan banjir, dan dataran banjir. Mengenai pencegahan pencemaran dalam konservasi sungai diatur oleh Pasal 27, yaitu:

(I)Pencegahan pencemaran air sungai sebagaimana dimaksud dalam Pasal 20 ayat (I) huruf b dilakukan melalui:

a. penetapan daya tampung beban pencemaran;

b. identifikasi dan inventarisasi sumber air limbah yang masuk ke sungai;

c. penetapan persyaratan dan tata cara pembuangan air limbah;

d. pelarangan pembuangan sampah ke sungai;

e. pemantauan kualitas air pada sungai; dan

f. pengawasan air limbah yang masuk ke sungai.

(2)Pencegahan pencemaran air sungai dilaksanakan sesuai dengan dengan ketentuan peraturan perundang-undangan.

Penerapan detail strategi kebijakan konservasi sungai diatur oleh Dinas PUPR Kota
Banjarmasin dan Dinas Lingkungan Hidup Kota Banjarmasin. Dinas PUPR Kota Banjarmasin dalam pengelolaan sungai telah merumuskan isu strategis yaitu: Revitalisasi sungai bagi kehidupan masyarakat (Dinas Pekerjaan Umum dan Penataan Ruang Kota Banjarmasin: 54), yang dituangkan dalam beberapa kebijakan Dinas PUPR Kota Banjarmasin, yaitu: a) Penyesuaian RTRW menjadi Berbasis Sungai, b) Peningkatan Penataan dan Revitalisasi Sumber Daya Air, dan c) Pelaksanaan Normalisasi Saluran Sungai. (Dinas Pekerjaan Umum dan Penataan Ruang Kota Banjarmasin: 54).

Kebijakan Dinas PUPR Kota Banjarmasin tersebut di atas kemudian dijabarkan dalam program Pengembangan, Pengelolaan, dan Konservasi Sungai, Danau dan Sumber Daya Air lainnya, yang terdiri dari Revitalisasi dan Penataan Bantaran Sungai (Debt Swap), Pelaksanaan Bakti Bersih Sungai, dan Revitalisasi dan Penataan Bantaran Sungai. (Dinas Pekerjaan Umum dan Penataan Ruang Kota Banjarmasin: 59)

Bidang Sungai PUPR telah melaksanakan berbagai kegiatan pengelolaan sungai seperti bersih-bersih sungai yang sering dilaksanakan dan/atau dipelopori oleh Bidang Sungai Dinas PUPR Kota Banjarmasin. Hal tersebut juga dipertegas oleh salah seorang petugas Dinas PUPR Kota Banjarmasin, Muhammad Kalam. Dia mengatakan bahwa Dinas PUPR Kota Banjarmasin sering membersihkan aliran-aliran sungai dari tumpukan sampah yang merupakan hasil kiriman dari hulu maupun sampah yang berasal dari masyarakat bantaran sungai. (Muhammad Kalam: 2020). Dinas PUPR Kota Banjarmasin juga melaksanakan revitalisasi dan penataan bantaran sungai yang dalam beberapa tahun ini dan masih dilakukan dengan merelokalisasi permukiman masyarakat bantaran sungai ke tempat daerah lain yang lebih layak.

Dalam melaksanakan kebijakan pengelolaan sungai di Kota Banjarmasin yang diantaranya adalah dengan mengkonservasi sungai, Bidang Sungai Dinas PUPR Kota Banjarmasin telah berhasil mewujudkan capaian kinerja pelayanan dari 20 I I-20I5 yaitu sepanjang $43.43 \mathrm{Km}$ sungai yang sudah ditangani, dengan rincian: tahun 2011 sepanjang 6,10 km, tahun 2012 sepanjang 9,6I $\mathrm{km}$, tahun 2013 sepanjang $7,07 \mathrm{~km}$, tahun 2014 
sepanjang $10,4 \mid \mathrm{km}$, dan pada tahun 2015 sepanjang 10,24 km. (Dinas Pekerjaan Umum dan Penataan Ruang Kota Banjarmasin: 54).

Dalam pelaksanaan konservasi sungai, terdapat beberapa permasalahan yang dihadapi oleh Bidang Sungai Dinas PUPR Kota Banjarmasin, Dinas Pekerjaan Umum dan Penataan Ruang Kota Banjarmasin: 40-4I), yaitu: a. Untuk menjalankan kebijakan "Mewujudkan kota Banjarmasin indah dengan penataan kota berbasis tata ruang berbasis sungai guna terwujud kota yang asri dan harmoni”, Bidang Sungai PUPR Kota Banjarmasin menghadapi kendala sebagai berikut:

I) Adanya kebijakan-kebijakan tentang pengelolaan dan pemanfaatan sungai;

2) Dukungan dari organisasi masyarakat yang peduli akan pentingnya kelestarian sungai;

3) Sosialisasi tentang pengelolaan dan penataan sungai dan drainase;

4) Rendahnya kesadaran masyarat akan pentingnya fungsi dan keberadaan sungai dalam pemanfaatan sumber air yang tidak ramah lingkungan serta tidak memperhatikan aspek berkelanjutan;

5) Keterbatasan Dana dan Sumber Daya Manusia yang dimiliki dibidang pengairan dan pengawasan;

6) Kurangnya peralatan dan personil pendukung operasional untuk tanggap darurat; dan

7) Belum optimalnya sinergitas dan koordinasi antara stakeholder terkait dalam pengelolaan sumber daya air.

b. Untuk menjalankan kebijakan "Meningkatkan kualitas lingkungan hidup". Dalam mewujudkan strategi kebijakan ini, Bidang Sungai PUPR Kota Banjarmasin menghadapi kendala sebagai berikut:

I) Alokasi dana yang terbatas;

2) Dinamika pembangunan yang cepat dan pesatnya pertumbuhan penduduk menurunkan kualitas ruang;

3) Ketergantungan masyarakat akan pemenuhan kebutuhan air langsung dari sumbernya;

4) Kurangnya dukungan masyarakat dalam pengelolaan sampah dan air limbah;

5) Komitmen pemerintah untuk menyediakan ruang terbuka hijau;

6) Adanya kebijakan pembangunan pemukiman baik dari pemerintah maupun swasta dengan jaringan air bersih sistem sanitasi yang memadai; dan

7) Pemasangan pengumuman/himbauan.

Adapun dinas lain yang terlibat menangani pengelolaan lingkungan terkait kebersihan sungai adalah Dinas Lingkungan Hidup (DLH) Kota Banjarmasin. DLH Kota Banjarmasin mempunyai tugas pokok menyusun perencanaan dan melaksanakan kebijakan daerah dalam bidang penataan lingkungan, pengawasan dan pengendalian perencanaan lingkungan, serta pelayanan dan pengolahan kebersihan. (Dinas Lingkungan Hidup Kota Banjarmasin: 2)

Program kerja yang sudah dilaksanakan oleh DLH Kota Banjarmasin terkait dengan kebijakan konservasi sungai oleh Pemerintah Kota Banjarmasin yaitu pengawasan dan pengendalian lingkungan, pemantauan dan pemulihan kualitas lingkungan serta pengevaluasian melalui pelaksanaan program dan kegiatan. (Dinas Lingkungan Hidup Kota Banjarmasin: 18-19). Isu yang paling menonjol yang ditekankan oleh DLH adalah masalah pencemaran air sungai. Karena itu, DLH rutin melakukan kegiatan uji kualitas air sungai di beberapa lokasi sungai di Kota Banjarmasin yang dilaksanakan oleh Bidang Tata Lingkungan pada Dinas Lingkungan Hidup (DLH) serta UPTD Laboratorium Lingkungan Hidup. (Dinas Lingkungan Hidup Kota Banjarmasin: 19)

Pengelolaan sungai pada saat penelitian ini dilaksanakan berpedoman pada Peraturan Daerah Kota Banjarmasin Nomor I5 Tahun 2016 tentang Upaya Peningkatan Pengelolaan Sungai, tetapi secara substansi lebih mengacu pada Peraturan Daerah Kota Banjarmasin Nomor 2 Tahun 2007 tentang Pengelolaan Sungai (Widodo, dkk: 19).

Pada umumnya kebijakan konservasi sungai yang dilaksanakan oleh Pemerintah Kota Banjarmasin masih belum dapat dikatakan berjalan secara efektif, karena dari data yang diperoleh dari wawancara yang dilakukan, terlihat bahwa sebagian besar masyarakat kota Banjarmasin yang hidup dan bermukim di lingkungan atau di bantaran sungai masih belum mengetahui tentang konservasi sungai tersebut. Sebagai contoh, Ibu Sapriah (Informan I) dan Bapak Yadi (Informan IX) yang bermukim di bantaran Sungai Pengambangan, mereka berdua tidak mengetahui sama sekali adanya kebijakan konservasi sungai yang diterapkan oleh 
Budi Rahmat Hakim, Abdul Hafiz Sairazi dan Nasrullah, 202I,Paradigma Fikih Sungai: Telaah Kebijakan Pemerintah dan Pemahamaan Masyarakat terhadap Konservasi Sungai di Kota Banjarmasin

Pemerintah Kota Banjarmasin (Sapriah: 2020). Namun, dari beberapa informan lain, sebagian kecil mengetahui tujuan dari dilaksanakannya konservasi sungai salah seorangnya adalah Muhammad Sidik (Informan VI), yang menyampaikan bahwa tujuan ataupun fungsi dari diberlakukannya konservasi sungai adalah sebagai upaya pengembalian fungsi sungai untuk aliran, pembebasan lahan di sekitar sungai, menjadikan sungai sebagai tempat wisata dan rekreasi. (Muhammad Sidik: 2020).

Meskipun kebanyakan masyarakat bantaran sungai di Kota Banjarmasin tidak mengetahui dan/atau tidak mengerti tentang kebijakan konservasi sungai yang dilaksanakan oleh Pemerintah Kota Banjarmasin, akan tetapi secara parsial mereka sudah sangat memahami penerapan konservasi sungai tersebut. Gambaran ini didapat dari jawaban semua informan yang menyatakan bahwa ada larangan bagi masyarakat Kota Banjarmasin membuang sampah ke aliran sungai.

\section{Respon Masyarakat Muslim Kota Banjarmasin terhadap Kebijakan Pemerintah terkait Upaya Konservasi Sungai}

Berdasarkan hasil wawancara, diperoleh data bahwa pada umumnya pengetahuan dan pemahaman masyarakat sekitar/ bantaran sungai tersebut mengenai kebijakan konservasi sungai hanya sampai pada ketentuan-ketentuan yang berkenaan dengan aturan larangan membuang sampah sembarangan ke sungai, sanksi denda bagi pelaku yang membuang sampah sembarangan termasuk ke sungai, dan anjuran membersihkan sungai secara rutin.

Pernyataan tersebut di atas peneliti kemukakan setelah mendengar dan mempelajari informasi-informasi yang diperoleh. Misalnya, seperti salah seorang informan yang tinggal di sekitar wilayah bantaran sungai Pengambangan mengatakan bahwa dirinya sangat mendukung ketentuan Pemerintah Kota Banjarmasin tersebut karena akan memberikan efek jera jika benar benar diterapkan (Ipah: 2020). Menurut informan lainnya, seorang ibu yang merupakan pedagang di daerah bantaran Sungai Kelayan, menuturkan bahwa dia tidak mengetahui adanya aturan-aturan dari pemerintah terkait pemanfaatan dan pemeliharaan sungai. (Ipah: 2020).

Sedangkan seorang informan yang bermukim di bantaran Sungai Martapura di daerah Basirih, bahwa pemerintah sudah sering melaksanakan sosialisasi mengenai larangan membuang sampah ke sungai dan bahwa eksistensi sampah dan kotoran di sungai bagi masyarakat, akan tetapi masih belum dapat menyadarkan masyarakat sepenuhnya. Di antara mereka masih banyak membuang sampai ke sungai meskipun TPS sudah disediakan, dan masih sering membuang kotoran ke sungai meskipun WC umum sudah dibangunkan oleh Pemerintah Kota Banjarmasin. (Informan V: 2020)

Berdasarkan semua data yang diperoleh dari penelitian ini, peneliti menemukan bahwa masyarakat masih belum mampu memahami secara baik urgensi dari kebijakan konservasi sungai yang dilaksanakan oleh pemerintah meskipun mereka menyadari dan mengetahui akan pentingnya keberadaan sungai bagi kehidupan mereka.

\section{D.Dukungan Pemahaman Keagamaan Masyarakat Muslim di Kota Banjarmasin terhadap Pemanfaatan dan Konservasi Sungai}

Keterlibatan masyarakat yang bermukim di bantaran sungai di kota Banjarmasin bervariasi, tergantung daerah masing-masing. Namun secara umum dilakukan dengan kegiatan gotong royong pembersihan sungai baik yang diselenggarakan secara mandiri oleh masyarakat maupun yang didorong dan difasilitasi oleh pemerintah Kota Banjarmasin melalui Bidang Sampah Dinas Lingkungan Hidup maupun yang langsung dikoordinasi oleh Bidang Sungai Dinas Pekerjaan Umum dan Penataan Ruang.

Dari beberapa informan yang diwawancarai, diperoleh keterangan bahwa keterlibatan masyarakat dalam penerapan konservasi sungai adalah dengan mengikuti kegiatan gotong royong untuk membersihkan sungai di lingkungan mereka bermukim. Menurut Fatma (Informan VII), sebagai bagian masyarakat yang hidup di salah satu bantaran sungai kota Banjarmasin dia mendukung sepenuh kegiatan masyarakat dalam membersihkan sungai. Dia menghimbau agar masyarakat ikut melaksanakan apa yang sudah 
menjadi kebijakan pemerintah mengenai konservasi sungai ini. (Fatma: 2020)

Adapun M. Sidik, dia sangat setuju dan mendukung kegiatan konservasi sungai demi kenyamanan masyarakat kota Banjarmasin. Selain itu, dia menegaskan bahwa sungai merupakan ciri khas Kota Banjarmasin dan telah banyak membawa manfaat bagi Kota Banjarmasin ini. Oleh karena itu selain mengikuti gotong royong, salah satu wujud dukungan terhadapa konservasi sungai menurut Sidik adalah dengan selalu berusaha untuk tidak membuang sampah ke sungai apalagi sampah yang tidak mudah terurai seperti plastik dan botol kaca. (Muhammad Sidik: 2020).

Lain lagi halnya dengan Ibu Sapriah (Informan I) dan Bapak Yadi (Informan IX). Selain mengikuti kegiatan gotong royong, mereka juga sering dilibatkan dalam rapat-rapat yang diselenggarakan oleh RT maupun Kelurahan dalam rangka membahas kebijakan untuk konservasi sungai di daerah mereka. (Sapriah: 2020). Bahkan kedua informan tersebut juga menegaskan bahwa mereka juga sering mengingatkan masyarakat yang tidak patuh terhadap kebijakan konservasi sungai dengan membuang sampai ke aliran sungai bahwa perilaku mereka berkonsekuensi denda karena melanggar ketentuan Perda Kota Banjarmasin tentang larangan membuang sampai ke sungai. (Sapriah: 2020).

Berdasarkan uraian di atas, ditemukan bahwa keterlibatan masyarakat bantaran sungai dalam penerapan kebijakan konservasi sungai yang telah dijalankan oleh Pemerintah Kota Banjarmasin adalah dengan melaksanakan kegiatan gotong royong pembersihan lingkungan dan aliran sungai, baik itu membersihkan sampah-sampah yang mengalir di aliran sungai maupun yang berserakan di lingkungan sekitar sungai. Selain itu, terdapat juga budaya saling mengingatkan di antara masyarakat dalam hal menjaga kelestarian sungai sehingga dapat dimanfaatkan dan agar tidak melanggar aturan/kebijakan yang telah ditetapkan oleh Pemerintah Kota Banjarmasin.

Terkait dengan informasi mengenai pemahaman keagamaan masyarakat Kota Banjarmasin, dapat dilihat dari hasil wawancara dengan para informan di mana di antaranya Muhammad Sidik, seorang informan yang tinggal di sekitar bantaran sungai wilayah Seberang
Mesjid yang menjelaskan bahwa ajaran agama Islam tentang menjaga sungai yang dia pahami salah satunya adalah siapa yang menjaga aliran sungai akan mendapatkan ganjaran pahala. Menurutnya, masyarakat jangan membuang sampah sembarangan, karena bersih adalah sebagian dari iman. Sidik menceritakan bahwa ustadz-ustadz mengimbau melalui ceramah agama dengan menjaga kebersihan lingkungan melalui fikih lingkungan dan menjaga kebersihan apa saja, termasuk kebersihan sungai. (Sapriah: 2020).

Ibu Ipah seorang Informan yang bermukim di lingkungan Sungai Kuin juga tidak pernah mendengar anjuran/himbauan dari ulama/ustadz untuk melestarikan sungai, bahkan menurutnya keberadaan sampah di Sungai Kuin semakin bertambah banyak setiap tahunnya, akan tetapi tidak ada petugas yang membersihkan sungai. (Ipah: 2020). Informan V yang bermukim di sekitar Sungai Kelayan juga mengatakan hal serupa, bahwa tidak ada himbauan tokoh masyarakat dan tokoh agama mengenai pelestarian sungai. (lpah: 2020)

Meskipun tidak pernah mendengar ajakan dari ulama atau tuan guru atau ustadz untuk menjaga kelestarian dan kebersihan sungai agar bisa memanfaatkannya dengan baik, Informan IV mengetahui secara jelas bahwa kebersihan adalah sebagian dari iman maka dari itu menjaga kebersihan sungai juga termasuk beribadah. (Informan IV: 2020).

Selain dari itu, hal yang paling miris adalah bahwa meskipun sosial budaya masyarakat Kota Banjarmasin merupakan budaya yang kental diwarnai ajaran Islam, namun dalam implementasinya sebagian masyarakat yang bermukim di bantaran sungai kurang diberikan sosialisasi, himbauan dan/atau ajaran mengenai pelaksanaan fikih sungai dari tokoh-tokoh agama setempat, yang salah satunya adalah menjaga, memelihara dan melestarikan sungai.

\section{E. Temuan}

Pada dasarnya, pemanfaatan sungai oleh masyarakat Kota Banjarmasin yang tinggal di sekitar bantaran sungai tidak jarang menimbulkan problem terhadap keberadaan sungai itu sendiri. Keberadaan rumah tinggal yang tidak hanya berdiri di bantaran sungai tapi bahkan juga tidak sedikit yang berdiri di atas sungai di samping mempersempit luasan sungai 
yang ada juga menyebabkan pencemaran sungai akibat limbah rumah tangga yang dibuang langsung ke sungai. Lebih fatalnya, pembuangan sampah rumah tangga ke sungai yang dilakukan sebagian masyarakat seolah sudah tidak menjadi hal yang tabu lagi. (Fitriansyah, dkk: II7). Mereka beranggapan bahwa sampah yang mereka buang akan terbawa arus ke hilir dan hilang dengan sendirinya, padahal sampah non organik disamping menimbulkan pencemaran, sifatnya juga tidak akan hancur dan akan mengendap ke bawah sehingga terjadi pendangkalan.

Oleh karena itu, sebagai upaya menyelamatkan keberadaan sungai dan kualitas hidup masyarakat di sekitar bantaran sungai, Pemerintah Kota Banjarmasin dalam program kebijakannya telah menetapkan sungai sebagai bagian dari aset kota. Pemerintah Kota Banjarmasin gencar mengembangkan sarana publik dan fasilitas pendukung wisata di sepanjang bantaran sungai untuk membangun citra kota. Pemko Banjarmasin juga memberikan bantuan pembangunan fasilitas MCK untuk rumah tangga sebagai alternatif pengganti jamban yang dibangun masyarakat di atas sungai. Penetapan jalur hijau dengan penataan rumah tinggal maupun bangunan lainnya yang beradaa di sekitar bantaran sungai juga semakin gencar dilakukan sebagai upaya menghidupkan kembali keberadaan sungai dan menjaga kelestariannya. Kebijakan dan program pengelolaan sungai secara khusus didelegasikan kepada satuan kerja perangkat daerah melalui Dinas Pekerjaan Umum dan Penataan Ruang (PUPR) Kota Banjarmasin Up. Bidang Sungai dan Dinas Lingkungan Hidup (DLH) Kota Banjarmasin.

Kebijakan konservasi sungai yang ditetapkan oleh Pemerintah Kota Banjarmasin adalah suatu bentuk kebijakan publik. Menurut Thomas R. Dye (198I) yaitu: "Public policy is whatever governments choose to do or not to do". Dye berpendapat bahwa kebijakan publik adalah apapun yang dipilih pemerintah untuk dilakukan atau tidak dilakukan. Dalam perspektif teori kebijakan publik, langkah-langkah yang dilakukan oleh Pemerintah Kota Banjarmasin tersebut tentu saja harus disesuaikan dengan kondisi daerah dan fakta sosiologis masyarakat Kota Banjarmasin. Implementasi kebijakan publik yang dilakukan oleh pemerintah daerah, dalam hal ini Pemerintah Kota Banjarmasin harus mengacu pada ketentuan-ketentuan kebijakan pemerintah pusat.

Sesuai kondisinya, sungai-sungai di Kota Banjarmasin merupakan sumberdaya yang mengalir, dimana pemanfaatan di daerah hulu akan mengurangi manfaat di hilirnya. Sebaliknya perbaikan di daerah hulu manfaatnya akan diterima di hilirnya. Berdasarkan hal tersebut diperlukan suatu perencanaan terpadu dalam pengelolaan DAS dengan melibatkan semua sektor terkait, seluruh stakeholder dan daerah yang ada dalam lingkup wilayah DAS dari hulu hingga ke hilir. (Direktorat Kehutanan dan Konservasi Sumberdaya Air: 16)

Secara sosiologis, kebijakan pemerintah akan dapat berjalan secara efektif jika direspon positif oleh masyarakat dan stakeholder terkait. Sebuah peraturan juga akan dapat terimplementasi dengan baik jika mendapat dukungan dan keterlibatan aktif masyarakat dalam mengawal dan merealisasikannya. Keterlibatan masyarakat dalam pengelolaan sungai di Kota Banjarmasin telah diatur dalam ketentuan yang termuat dalam Peraturan Daerah Kota Banjarmasin Nomor 2 Tahun 2007 tentang Pengelolaan Sungai. Partisipasi masyarakat tersebut dilibatkan dalam bentuk pemberdayaan masyarakat yang telah ditentukan pada Pasal II yang berbunyi:

(I) Setiap orang mempunyai hak yang sama atas kondisi sungai yang baik dan sehat;

(2) Setiap orang mempunyai hak atas informasi yang berkaitan dengan peran dalam pengelolaan sungai;

(3) Masyarakat dapat berperan aktif dalam perencanaan, pemanfaatan, perlindungan, dan pengawasan sungai;

(4)Masyarakat wajib ikut serta menjaga kelesatarian fungsi dan manfaat sungai; dan

(5)Masyarakat dapat membentuk kelompok yang berperan dalam pemanfaatan, perlindungan dan pengawasan sungai.

Kemudian dalam Peraturan Daerah Kota Banjarmasin Nomor I5 Tahun 2016 tentang Upaya Peningkatan Pengelolaan Sungai juga dijelaskan bahwa salah satu pemberdayaan tersebut adalah adanya partisipasi masyarakat dalam pengelolaan sungai. Partisipasi tersebut dapat diwujudkan dalam bentuk kegiatan- 
kegiatan yang dilakukan oleh komunitas masyarakat seperti kegiatan pembersihan sungai.

Adapun efektivitas penerapan kebijakan konservasi sungai yang ditetapkan oleh Pemerintah Kota Banjarmasin masih belum sepenuhnya berhasil. Keberhasilan penerapan kebijakan ini bisa dikatakan hanya sampai pada tersampaikannya informasi dalam sosialisasisosialisasi yang dilaksanakan oleh Bidang Sungai Dinas Pekerjaan Umum dan Penataan Ruang (PUPR) Kota Banjarmasin dan Bidang Sampah Dinas Lingkungan Hidup (DLH) Kota Banjarmasin mengenai menjaga sungai dari sampah dan/atau kotoran. Namun masih banyak masyarakat yang belum mengetahui dan memahami kebijakan konservasi sungai.

Perilaku masyarakat yang sudah terbiasa membuang sampah ke sungai dianggap seakanakan menjadi suatu hal yang lumrah. Padahal Islam sebagai agama yang mayoritas dianut masyarakat Kota Banjarmasin dengan jelas memberikan petunjuk menjaga kebersihan dan kesehatan (kemaslahatan) lingkungan. Problematika inilah yang menjadi penting untuk membumikan fikih sungai dalam kehidupan masyarakat Kota Banjarmasin yang religius, terutama yang hidup di sekitar atau di bantaran sungai-sungai di Kota Banjarmasin.

Sebenarnya apabila masyarakat mengetahui dan memahami konservasi sungai maupun kebijakan tentang hal tersebut maka akan melahirkan partisipasi masyarakat yang aktif. Sondang P. Siagian, sebagaimana yang dikutip oleh Khairuddin (1992: 125), mengemukakan pentingnya partisipasi masyarakat, yakni: "Partisipasi dari masyarakat luas mutlak diperlukan, oleh karena itu pada akhirnya melaksanakan berbagai kegiatan pembangunan, rakyat banyak memegang peranan sekaligus sebagai objek dan subjek pembangunan".

Dalam menerima suatu kebijakan masyarakat juga dituntut dapat memahami, menghayati, dan melaksanakannya. Namun perlu disadari bahwa dalam hal ini partisipasi masyarakat mutlak diperlukan dan tanpa adanya keterlibatan masyarakat maka konservasi sungai yang telah direncanakan tidak akan berhasil. Masyarakat Kota Banjarmasin terutama yang bermukim di bantaran sungai merupakan faktor utama keberhasilan program atau kebijakan konservasi sungai tersebut.
Faktanya, kebijakan konservasi sungai yang dilaksanakan oleh Pemerintah Kota Banjarmasin masih kurang diketahui oleh masyarakat yang bermukim di sekitar bantaran sungai, mereka hanya sebatas mengetahui adanya larangan membuang sampah ke sungai dan kurang memahami konsep dan tujuan dari konservasi sungai dalam pengertian yang lebih luas, sehingga dimungkinkan dengan demikian dukungan peran serta aktif dari masyarakat dalam upaya-upaya konservasi masih sangat terbatas. Padahal, keberadaan sungai bagi sebagian masyarakat bantaran sungai di Kota Banjarmasin masih memegang peranan yang cukup penting dalam berbagai segi kehidupan, bahkan masih banyak warga masyarakat yang memanfaatkan sungai untuk keperluan mandi dan cuci. Bantaran sungai ini juga dapat dijadikan sarana sosialisasi untuk belajar kebudayaan masyarakatnya. (Rochgiyanti: 58-59)

Meskipun distribusi air bersih yang disalurkan oleh Perusahaan Air Minum Bandarmasih Kota Banjarmasin telah sampai ke daerah bantaran sungai Kota Banjarmasin dan sekitarnya, tetapi masih terdapat beberapa manfaat sungai yang langsung dirasakan masyarakat yang hidup di sekitar bantaran atau pinggiran sungai. Dengan banyaknya manfaat langsung sungai bagi masyarakat terutama masyarakat yang hidup dan bermukim di sekitar atau di bantaran sungai, maka konservasi sungai merupakan suatu hal yang penting bahkan wajib dilaksanakan guna menjaga, memelihara dan melestarikan eksistensi sungai-sungai tersebut.

Berdasarkan hasil wawancara yang telah dilaksanakan pula, peneliti menilai bahwa sebagian besar masyarakat bantaran sungai Kota Banjarmasin menyatakan bahwa mereka cukup menyadari pentingnya pelestarian sungai agar manfaat dan fungsi sungai dapat mereka rasakan sebaik-baiknya. Namun kesadaran akan pentingnya pelestarian sungai tersebut tidak dibarengi dengan tingkat pengetahuan dan pemahaman keagamaan masyarakat setempat.

Secara umum sebagian besar informan hanya sebatas memahami bahwa Islam menganjurkan untuk menjaga kebersihan lingkungan dan perilaku hidup tidak sehat dan yang dapat mengotori atau menjadikan lingkungan menjadi rusak bertentangan dengan ajaran Islam. Adapun pengetahuan mereka terkait dengan pemanfaatan sungai dan pelestariannya dalam 
Budi Rahmat Hakim, Abdul Hafiz Sairazi dan Nasrullah, 202I,Paradigma Fikih Sungai: Telaah Kebijakan Pemerintah dan Pemahamaan Masyarakat terhadap Konservasi Sungai di Kota Banjarmasin

fikih masih dipahami secara terbatas dan berkenaan dengan pengaturan tentang sungai dan pemanfaatan sumber-sumber air tidak pernah mereka ketahui dan tidak pernah mereka dengar sebelumnya dalam ceramah-ceramah atau pesan-pesan keagamaan yang disampaikan para mubalig/da'i.

Minimnya pengetahuan masyarakat dan pemahaman mereka tentang ajaran fikih mengenai pemanfaatan dan pelestarian sumber air dan sungai ini menyebabkan terbatasnya persepsi dan dukungan sikap mereka terhadap upaya-upaya konservasi yang dilakukan pemerintah. Dakwah-dakwah agama baik berupa khutbah, ceramah maupun lainnya tentang lingkungan dan lebih khusus mengenai pentingnya menjaga dan melestarikan sungai yang semestinya menjadi edukasi yang efektif bagi masyarakat juga diakui masih jarang dilakukan.

Secara normatif, sebenarnya ajaran Islam sangat konsen dalam memperhatikan pentingnya menjaga kelestarian lingkungan. Pemeliharaaan sumber air dari pencemaran wajib dilakukan oleh semua pihak, baik masyarakat maupun pemerintah. Kewajiban ini didasarkan pada kaidah fiqhiyah: "maa laa yatimmu al wajib illa bihi fa huwa wajib", sesuatu yang menyebabkan suatu kewajiban tidak terlaksana secara sempurna, maka sesuatu itu menjadi wajib dilakukan untuk kesempurnaan pelaksanaan kewajiban tersebut. Dalam kaitan dengan pemeliharaan sumber air dari pemcemaran, ajaran agama Islam (fikih) sudah menunjukkan ke arah pencegahan yang sangat cermat. Ajaran Islam menghendaki ada tempat khusus untuk buang kotoran atau dengan kata lain buang kotoran tidak boleh dilakukan di sembarang tempat karena selain akan mengganggu kenyamanan lingkungan juga akan mencemarkan air, tanah, maupun udara. Dalam fikih juga disebutkan, air yang tercemar oleh kotoran manusia dan jenis kotoran lian adalah air najis atau air mutanajjis.

Dalam fikih juga dikenal konsep harim alnahar (Abu Jaib: 86 dan Athaillah: 40), yaitu membiarkan bantaran sungai kosong dari bangunan karena bantaran tersebut diperuntukkan bagi tindakan-tindakan yang diperlukan untuk konservasi sungai. Konsep itu tercantum dalam Imam al-Bijuri dan Ibnu Hajar
al-Haitami, Al-Bijuri bahkan merekomendasikan agar semua bangunan yang terlanjur didirikan di bantaran sungai, meskipun berupa mesjid, agar digusur. (Baijuri: 54). Penggusuran terhadap semua bangunan yang ada di bantaran sungai, menurut al-Haitami adalah hasil kesepakatan empat mazhab. (Haitami: 306-307)

Program-program kebijakan dan regulasi terkait pengelolaan sungai yang berorientasi pada pelestarian lingkungan hidup sebagaimana yang ditetapkan Pemerintah Kota Banjarmasin sudah cukup relevan dengan semangat ajaran Islam dan prinsip-prinsip maqashid al-syariah untuk menjamin kemaslahatan alam dan daya dukung hidup masyarakat secara lebih luas. Konsep fikih mengenai pemanfaatan air dan lingkungan sungai serta pelestarian eksistensi dan fungsinya dalam kehidupan seyogyanya juga menjadi landasan sekaligus pendorong sikap positif masyarakat dalam turut mendukung upaya-upaya konservasi sungai sehingga dengan demikian akan terbangun kesadaran privat dan moralitas publik dalam mewujudkan kemaslahatan lingkungan.

\section{PENUTUP}

Berdasarkan hasil penelitian dan pembahasan yang diuraikan di atas, dapat disimpulkan bahwa kebijakan Pemerintah Kota Banjarmasin dalam pengelolaan dan konservasi sungai terimplementasi dalam Rencana Tata Ruang Wilayah Kota Banjarmasin 2013-2032 dan dalam visi-misi Walikota Banjarmasin 2016-202I.

Kebijakan tersebut diatas dilaksanakan oleh Dinas Pekerjaan Umum dan Penataan Ruang Kota Banjarmasin melalui revitalisasi dan penataan bantaran sungai, pelaksanaan bakti bersih sungai dan revitalisasi dan penataan bantaran sungai. Dinas Lingkungan Hidup juga terlibat melalui bidang penataan lingkungan, pengawasan dan pengendalian perencanaan lingkungan, serta pelayanan dan pengolahan kebersihan. Upaya lain yang dilakukan Pemerintah Kota Banjarmasin yaitu penetapan jalur hijau di sekitar bantaran sungai. Kebijakan konservasi sungai mendapat respon positif dari masyarakat Kota Banjarmasin yang terwujud dalam bentuk gotong royong pembersihan lingkungan dan aliran sungai, namun partisipasi dan keterlibatan masyarakat terhadap konsevasi 
sungai masih rendah karena masih ada kebiasaan membuang sampah di sungai dan pembangunan rumah/bangunan di bantaran sungai meski sudah dilarang.

Adapun pemahaman keagamaan masyarakat muslim di Kota Banjarmasin dalam pemanfaatan dan konservasi sungai masih rendah karena belum didukung secara memadai oleh pengetahuan mereka terhadap konsep ajaran fikih dan aturan-aturan terkait konservasi lingkungan secara lebih luas. Fikih dalam pengetahuan mereka masih dipahami hanya sebagai aturan-aturan hukum yang terkait dengan ibadah saja. Sebagian besar informan juga mengaku belum memahami secara khusus bahwa menjaga, mengelola, dan melestarikan sungai dan sumber-sumber air merupakan bentuk pengamalan fikih yang menjadi bagian integral dari ajaran Islam.

Disarankan kepada pemerintah khususnya Pemerintah Kota Banjarmasin agar lebih mengintensifkan sosialisasi peraturan daerah maupun regulasi lain menyangkut pengelolaan sungai sehingga keberadaanya dapat berdaya guna dalam menjamin kemaslahatan sungai sebagai sumber daya air dan fasilitas publik. Kepada lembaga-lembaga keagamaan diharapkan dapat memberikan pemahaman ajaran agama tentang etika pemanfaatan sumber daya air dan sungai serta pentingnya konservasi lingkungan sehingga dapat turut membumikan fikih sungai dan membangun motivasi keagamaan yang mendukung upaya pelestarian dan perwujudan kemaslahatan lingkungan secara lebih luas. Kemudian, kepada seluruh lapisan masyarakat khususnya masyarakat yang tinggal di kawasan bantaran sungai agar dapat berperan serta secara aktif mendukung peraturan dan kebijakan konservasi sungai dari pemerintah melalui perilaku hidup bersih, menjaga sungai dan sumber air dari kerusakan lingkungan, serta melakukan pemanfaatan sungai secara bijak, sehingga kemaslahatan sungai dan lingkungan secara umum dapat terwujud sesuai dengan semangat ajaran Islam

\section{DAFTAR PUSTAKA}

Abdillah, Mujiono, Fikih Lingkungan; Panduan Spritual Hidup Berwawasan Lingkungan, Yogyakarta, UPP-AMP YKPN, 2005.

Abdullah, M. Amin, "Pelestarian Lingkungan Hidup Perspektif Islam”. Khazanah: Jurnal
Ilmu Agama Islam, Vol. 2 No. 7, Januari-Juli 2005.

Adi, Isbandi Rukminto. Pemberdayaan Pengembangan Masyarakat dan. Intervensi Komunitas. Jakarta: Fakultas Ekonomi UI, 2001.

Ariyadi, Ariyadi. "Metodologi Istinbath Hukum Prof. Dr. Wahbah Az Zuhaili." Jurnal Hadratul Madaniyah 4.I (2017): 32-39.

Ariyadi, Ariyadi, and Siti Maimunah. "Peran Agama Islam dalam Konservasi Hutan." Daun: Jurnal Ilmiah Pertanian Dan Kehutanan 4.2 (2017): 63-74.

Ariyadi, Ariyadi. "Nilai-Nilai Qurani dan Sunnah Nabi dalam Praktik Jual Beli Pada Pasar Terapung di Kalimantan Selatan." Anterior Jurnal I7.2 (20I8): II5-I 24.

Athaillah, "Persepsi Masyarakat Muslim Kota Banjarmasin terhadap Pengelolaan Sungai”, Jurnal Penelitian IAIN Antasari, No. 10, April 2004.

Badan Pusat Statistik Kota Banjarmasin. Statistik Daerah Kota Banjarmasin 2019, Banjarmasin: BPS Kota Banjarmasin, 2019.

\section{Banjarmasin} Lebarnya, https://banjarmasinkota.bps.go.id.

Bagian Umum Kota Banjarmasin, "Profil Kota Banjarmasin", https://umum. banjarmasinkota. go.id/2017/0I/profil-kota-banjarmasin.html.

Dinas Kebudayaan dan Pariwisata. Revisi Renstra Tahun 2016-2021, Banjarmasin: Dinas Kebudayaan dan Pariwisata, 2018.

Dinas Lingkungan Hidup Kota Banjarmasin. (Revisi) Rencana Strategis Dinas Lingkungan Hidup Tahun 2017-2021, Banjarmasin: Dinas Lingkungan Hidup, 2019.

Dinas Pekerjaan Umum dan Penataan Ruang Kota Banjarmasin. 2018. Revisi Rencana Strategis Tahun 2016-202I, Banjarmasin: Dinas PUPR Kota Banjarmasin.

Direktorat Kehutanan dan Konservasi Sumberdaya Air. "Kajian Model Pengelolaan Daerah Aliran Sungai (DAS) Terpadu”, sumber: https://www.bappenas.go.id/.../I7kajianmodel-pengelolaan-daerah-aliran- sungai-dasterpadu.

Dunn, William. Pengantar Analisis Kebijakan Publik. Yogyakarta: Gadjah Mada University Press, 2003.

Dwijowijoto, Ryant Nugroho. Kebijakan Publik Formulasi, Implementasi dan Evaluasi. Jakarta: PT. Elex Media Komputindo, 2003. 
Budi Rahmat Hakim, Abdul Hafiz Sairazi dan Nasrullah, 202I,Paradigma Fikih Sungai: Telaah Kebijakan Pemerintah dan Pemahamaan Masyarakat terhadap Konservasi Sungai di Kota Banjarmasin

Dye, Thomas R. Understanding Public Policy, 3th Englewood Cliffs, NJ; Prentice Hall, 198I.

Fitriansyah, Muhammad., Asmadi, Ayu Putri Kusmia Sari. Kualitas Air Sungai Pangambangan Kota Banjarmasin", http://ejournal.umm.ac.id/index.php/ jmts/article/view/6269, diakses tanggal 28 Mei 2020.

Gassing, A. Qadir, Etika Lingkungan dalam Islam, Jakarta, Pustaka Mapan, 2007.

Istiqomah, Ermina. dan Sudjatmiko Setyobudihon. "Nilai Budaya Masyarakat Banjar Kalimantan Selatan: Studi Indigenous", Jurnal Psikologi Teori dan Terapan, 2014, Vol. 5, No. I, I-6, ISSN: 2087-I708, 2014.

Khairuddin. Pembangunan Masyarakat Tinjauan Aspek: Sosiologi, Ekonomi, dan Perencanaan. Yogyakarta: Liberty, 1992.

Kodoatie, Robert J., dkk, Pengelolaan Sumber Daya Air dalam Otonomi Daerah, Penerbit Andi, Yogyakarta, 1992.

Maskuriah, Ulul, "Sungai di Banjarmasin dipenuhi sampah". Koran online http://www.antarakalsel.com/berita/ I 840 I/su ngai-banjarmasin-dipenuhi-sampah (diakses 16 Februri 2018).

Mentayani, Ira. "Identitas Dan Eksistensi Permukiman Tepi Sungai Di Banjarmasin”, Prosiding Seminar Nasional Lingkungan Lahan Basah, p-ISSN 2623-16II, e-ISSN 2623-1980, Vol. 4 No. 3 April 2019.

Peraturan Daerah Kota Banjarmasin Nomor 5 Tahun 2013 tentang Rencana Tata Ruang Wilayah Kota Banjarmasin 2013-2032.

Peraturan Pemerintah Nomor 38 Tahun 20II tentang Sungai.

Rama, Bahaking, "Pelestarian Lingkungan Ditinjau dari Ajaran Islam", Jurnal Khazanah, Vol. II No. 02 Maret-April 2003, IAIN Antasari Banjarmasin.

Rochgiyanti. "Fungsi Sungai Bagi Masyarakat Di Tepian Sungai Kuin Kota Banjarmasin”, Jurnal Komunitas, Vol. 3 No. I, ISSN 2086-5465, 2011.

Rosalina, Iga. "Efektivitas Program Nasional Pemberdayaan Masyarakat Mandiri Perkotaan pada Kelompok Pinjaman Bergulir di Desa Mantren Kecamatan Karangrejo Kabupaten Madetan”. Jurnal Efektivitas
Pemberdayaan Masyarakat, Vol. 0I No. 0I Februari 2012.

Soekanto, Soerjono dan Mustafa Abdullah, Sosiologi Hukum Dalam Masyarakat. Jakarta: Rajawali, 1980.

Sukarni, Bantaran Sungai dalam Perspektif Ajaran Islam, Makalah Seminar Kerjasama MUI Kalsel dengan Dinas Pengelolaan Sungai dan Drainase Kota Banjarmasin, Sabtu, 15 September 2012. , Islam dan Lingkungan Hidup, Banjarmasin, Majlis Pustaka dan Informasi PW Muhammadiyah Kalimantan Selatan, 2013.

Tachjan. Implementasi Kebijakan Publik. Bandung: AIPI dan Puslit, 2006.

Thalhah, M. dan Achmad Mufid A.R., Fiqih Ekologi: Menjaga Bumi Memahami Makna Kitab Suci, Yogyakarta: Total Media, Cet. I, 2008.

Undang-Undang Nomor 7 Tahun 2004 tentang Sumber Daya Air.

Widodo, Kukuh., Vera D. Damayanti, dan Setia Hadi. "Perencanaan Lanskap Sungai Kelayan Sebagai Upaya Revitalisasi Sungai di Kota Banjarmasin Kalimantan Selatan”, Jurnal Lanskap Indonesia, Vol. 4 No. I -20I2.

Yayuk, Risari. "Leksikon Pengungkap Karakteristik Budaya Sungai Masyarakat Banjarmasin dan Nagara: Telaah Etnosentris", Jurnal Naditira Widya, Vol. 12 No. 2 Oktober 2018 Balai Bahasa Kalimantan Selatan, 2018. 
